\title{
Usulan Pengendalian Pe rsediaan Peralatan dan Perlengkapan Hotel, Restoran, dan Café di Mr. Kitchen
}

\author{
Proposed Inventory Control for Hotel, Restaurant, and Café Equipment and Supplies at \\ Mr. Kitchen
}

\author{
Melvita Samudra, Kartika Suhada \\ Program Studi Teknik Industri Universitas Kristen Maranatha \\ E-mail: me17samudra@gmail.com, kartika.suhada@eng.maranatha.edu
}

\begin{abstract}
Abstrak
PT. Multi Wahana Kencana atau lebih dikenal dengan sebutan Mr. Kitchen adalah perusahaan yang bergerak dalam bidang penyedia peralatan dan perlengkapan horeca (hotel, restoran, dan café, yang berada di Jl. Garuda, Bandung. Masalah yang dihadapi perusahaan adalah kelebihan persediaan barang di gudang yang menyebabkan biaya simpan membesar.

Dalam penelitian ini diusulkan dua alternatif metode pengendalian persediaan, yaitu metode $P$ $(t, E)$ dan metode Monte Carlo. Perhitungan metode saat ini dan metode $P(t, E)$ dilakukan beberapa penyesuaian, yaitu penyesuaian pada demand dan cara perhitungan. Berdasarkan hasil pengolahan data, total biaya metode saat ini adalah sebesar Rp. 4,207,814,304.40. Metode usulan yang mempunyai total biaya terkecil adalah metode Monte Carlo yaitu Rp. 1,356,682,580.71, dimana didapatkan penghematan sebesar Rp. 2,851,131,723.69 atau 67.76\%. Penghematan didapatkan dari penurunan biaya simpan sebesar Rp. 3,210,543,597.88 atau $89.14 \%$ dan biaya pesan sebesar Rp. 218,404,023.30 atau 80.77\%. Walaupun biaya stockout meningkat sebesar Rp 577,815.897.49 atau $172.12 \%$.
\end{abstract}

Kata kunci:pengendalian persediaan, Metode P $(t, E)$, Metode Monte Caro

\begin{abstract}
PT. Multi Wahana Kencana or better known as Mr. Kitchen is a company engaged in horeca (hotel, restaurant, and café) equipment and supplies field, located in Jl. Garuda, Bandung. The problem faced by the company is overstock inventory in warehouse, which cause increasing in holding cost.

In this research two alternative inventory control method are proposed, there are $P(t, E)$ method and Monte Carlo method. Adjustments were made for current method and $P(t, E)$ method, there are demand adjustment and method calculation adjustment. Based on the data calculation, total cost for current method about IDR 4,207,814,304.40. Proposed method which has minimum total cost is Monte Carlo Method about IDR 1,356,682,580.71, and make savings about IDR 2,851,131,723.69 or 67.76\%. The savings obtained from holding cost reduction about IDR 3,210,543,597.88 or 89.14\% and ordering cost reduction about IDR. 218,404,023.30 or $80.77 \%$. Although stockout cost increases about IDR 577,815.897.49 or $172.12 \%$.
\end{abstract}

Keywords: inventory control, $P(t, E)$ method, Monte Carlo Method

\section{Pendahuluan}

Dalam situasi persaingan yang semakin ketat, setiap perusahaan dituntut untuk dapat memberikan pelayanan yang memuaskan kepada konsumennya. Salah satunya adalah dapat menyediakan barang yang dibutuhkan konsumen tepat pada waktunya. Hal ini menuntut adanya persediaan barang yang memadai. Jika persediaan terla lu banyak maka biaya simpan yang timbul akan tinggi. Jika persediaan terlalu sedikit maka akan terjadi stockout yang dapat merugikan perusahaan. Mr. Kitchen adalah perusahaan yang bergerak dalam bidang penyedia peralatan dan perlengkapan horeca (hotel, restoran, dan café), catering, dan alat prasmanan stainless. Barang-barang yang dijual perusahaan diperoleh dari supplier luar negeri. Permasalahan yang dihadapi perusahaan adalah penumpukan barang di dalam gudang yang disebabkan kurang tepatnya metode pengendalian persediaan yang diterapkan perusahaan. Perusahaan melakukan pemesanan berdasarkan perkiraan dari Kepala Gudang, dimana periode pemesanan ditetapkan perusahaan 
dibedakan berdasarkan supplier. Disamping itu, perusahaan belum mempertimbangkan elemenelemen biaya pengendalian persediaan. Oleh karena itu, diusulkan metode pengendalian persediaan yang menghasilkan total biaya pengendalian persediaan terkecil.

Batasan masalah yang digunakan adalah sebagai berikut:

1. Data permintaan dari periode Mei 2018 hingga April 2019.

2. Produk yang diamati adalah produk dengan klasifikasi kelas A berdasarkan supplier.

Asumsi masalah yang digunakan adalah sebagai berikut:

1. Pola permintaan masa yang akan datang mengikuti pola permintaan masa lalu.

2. Besar elemen biaya pengendalian persediaan tidak berubah selama periode perencanaan

Berdasarkan perumusan masalah di atas, maka tujuan dilakukannya penelitian ini adalah:

1. Menganalisis kekurangan metode pengendalian persediaan perusahaan saat ini.

2. Memberikan usulan pengendalian persediaan yang sebaiknya diterapkan perusahaan.

3. Mengemukakan manfaat yang didapatkan oleh perusahaan dari pengendalian persediaan usulan.

\section{Tinjauan Pustaka}

\subsection{Pengertian pe rsediaan}

Menurut Rangkuti (2004), persediaan adalah bahan, bagian yang disediakan, dan bahan dalam proses yang terjadi di perusahaan dalam menjalankan proses produksi, serta barang jadi yang disajikan untuk memenuhi permintaan dari konsumen setiap waktu. Persediaan dapat terdiri dari beberapa macam, yaitu (Yamit, 1999):

1. Persediaan alat kantor, merupakan persediaan yang diperlukan untuk melakukan kegiatan perusahaan

2. Persediaan bahan baku, merupakan barang yang dibeli dari supplier, yang akan digunakan sebagai input dalam melakukan proses produksi dalam perusahaan.

3. Persediaan barang dalam proses, merupakan produk akhir tapi masih berada pada proses pengerjaan

4. Persediaan barang jadi, merupakan persediaan produk akhir yang akan dijual, didistribusikan, dan disimpan oleh perusahaan

\subsection{Biaya pe ngendalian perse diaan}

Adapun biaya-biaya pengendalian persediaan adalah (Tersine, 1994):

1. Purchase Cost (Biaya Pembelian)

Biaya pembelian adalah biaya untuk membeli barang jika diperoleh dari luar atau dapat pula memproduksi barang jika barang tersebut diproduksi oleh perusahaan itu sendiri.

2. Order /Setup Cost (Biaya Pemesanan)

Biaya pemesanan merupakan biaya yang timbul pada saat dilakukan pemesanan untuk

memenuhi persediaan yang dimiliki. Atau biaya persiapan, yaitu biaya yang timbul apabila perusahaan memproduksi sendiri barangnya

3. Holding Cost (Biaya Penyimpanan)

Biaya penyimpanan adalah biaya yang diasosiasikan dengan investasi dalam persediaan dan untuk mempertahankan investasi fisik da lam gudang. Komponen pembentuk biaya simpan adalah biaya modal, pajak, asuransi, dan penyusutan.

4. Stockout Cost (Biaya kekurangan persediaan)

Merupakan biaya yang dikenakan jika tidak terdapat persediaan yang cukup untuk memenuhi permintaan berlebih yang datang pada suatu saat tertentu. Terdapat 2 jenis kekurangan yaitu backorder cost dan lost sales cost. 


\subsection{Metode pengendalian persediaan}

\subsubsection{Metode $\mathbf{P}(\mathbf{t}, \mathbf{E})$}

Menurut Tersine (1994) dan Yamit (1999), metode P (t, E) atau sering juga disebut sebagai sistem persediaan periodik. Dalam Metode P (t, E) jumlah item dalam persediaan ditinjau berdasarkan interval waktu yang tetap. Ukuran penggantian pesanan bergantung pada jumlah unit persediaan.

Penjabaran formulasi yang digunakan pada pengendalian persediaan metode $\mathrm{P}(\mathrm{t}, \mathrm{E})$ adalah (Tersine, 1994 dan Smith, 1989):

1. Biaya pesan

Biaya pesan/tahun akan bergantung pada besarnya ekspektasi frekuensi pemesanan (f) dan biaya yang diperlukan dalam melakukan pemesanan

Biaya pesan $=\mathrm{f} \times \mathrm{C}$

Biaya pesan $=\frac{(C+n c)}{t}$

Keterangan: $\quad \mathrm{C}=$ biaya pesan yang nilainya tidak dipengaruhi jumlah jenis barang ( $\mathrm{Rp} / \mathrm{pesan})$

$\mathrm{c}$ = biaya pesan yang nilainya dipengaruhi jumlah jenis barang (Rp/pesan)

$\mathrm{n}=$ jumlah jenis barang

$\mathrm{t}=$ periode pemesanan (bulan)

2. Biaya simpan

Biaya simpan/tahun akan bergantung pada besarnya ekspetasi jumlah persediaan yang disimpan (m) dan biaya simpan/unit/tahun $(\mathrm{H})$

Biaya simpan $=\mathrm{H} \times \mathrm{m}$

a) Kasus back order

$$
\text { Biaya simpan }=\mathrm{H}\left(\mathrm{E}-\mu_{\mathrm{L}}-\frac{R x t}{2}\right)
$$

Keterangan:

$\mathrm{E}=$ persediaaan maksimum (unit)

$\mu_{\mathrm{L}}=$ besar ekspetasi selama horizon perencanaan sebesar $\mathrm{R}$ dan lead time (unit)

$\mathrm{R}=$ rata-rata demand (unit)

b) Kasus lost sales

Biaya simpan $=H\left(E-\mu_{L}-\frac{R x t}{2}+N_{k}\right)$

3. Biaya stockout

Biaya stockout atau biaya kekurangan merupakan biaya yang dikarenakan perusahaan tidak mampu memenuhi permintaan konsumen. Terdapat 2 jenis kekurangan yaitu backorder cost dan lost sales cost. Biaya ini dapat ditentukan dari keadaan nyata yang dialami oleh perusahaan atau berdasarkan hasil perhitungan.

4. Total biaya

Rumusan matematis total biayanya adalah sebagai berikut:

a) Kasus back order

Biaya total back order = biaya pesan + biaya simpan + biaya stockout

$$
=\left(\frac{C+n c}{t}\right)+H\left(E-\mu_{L}-\frac{R x t}{2}\right)+\left(\frac{\pi}{t}\right) N_{k}
$$

b) Kasus lost sales

Biaya total lost sales = biaya pesan + biaya simpan + biaya stockout

$$
=\left(\frac{C+n c}{t}\right)+H\left(E-\mu_{L}-\frac{R x t}{2}+N_{k}\right)+\left(\frac{\pi}{t}\right) N_{k}
$$

5. Variabel keputusan optimal

Agar memperoleh nilai variabel keputusan $t$ dan $E$ yang optimal, digunakan prinsip optimasi dengan memanfaatkan sifat konveksitas biaya total (OT) terhadap t dan $\mathrm{E}$. 
a) $\partial t$

Kasus back order

$t=\sqrt{\frac{2(C+n c)}{F \sum_{i=1}^{n}\left(P_{i} x R_{i}\right)}}$

Keterangan:

$\mathrm{F} \quad=$ persentase biaya simpan/tahun

$\sum_{i=1}^{n}\left(P_{i} x R_{i}\right) \quad=$ total biaya pembelian untuk jenis barang i selama horizon perencanaan

$\mathrm{P}_{\mathrm{i}} \quad=$ harga beli untuk barang jenis $\mathrm{i}$

$\mathrm{R}_{\mathrm{i}} \quad=$ ekspetasi permintaan untuk barang jenis i selama horizon perencanaan

Kasus lost sales

$t=\sqrt{\frac{2(C+n c)}{F \sum_{i=1}^{n}\left(P_{i} x R_{i}\right)}}$

b) $\partial B$

$\frac{\partial O_{T}}{\partial B}=0$

Kasus back order

$\int_{B}^{\infty} f(z) d z=\frac{H t}{\pi}$

Keterangan: $F^{\prime}(k)=$ probabilitas terjadinya kekurangan persediaan

Kasus lost sales

$$
\int_{E}^{\infty} f(z) d z=\frac{H t}{H t+\pi}
$$

Langkah-langkah untuk me lakukan pengendalian persediaan metode $\mathrm{P}(\mathrm{t}, \mathrm{E})$ adalah sebagai berikut (Tersine, 1994 dan Smith, 1989):

1. Menghitung nilai t yaitu periode pemesanan

2. Menghitung $F^{\prime}(\mathrm{K})$

3. Menentukan nilai $\mathrm{K}$ dari tabel normal. Jika tidak ada nilai pas, maka dilakukan interpolasi.

4. Menghitung batas persediaan maksimum

\subsubsection{Metode Monte Carlo}

Pengertian simulasi menurut Heizer dan Render (2012) adalah upaya untuk menduplikasi fitur, penampilan, dan karakteristik sistem yang nyata. Simulasi ini akan digunakan dalam membangun model matematika yang sedekat mungkin dapat mewakili sistem yang nyata, dan kemudian akan digunakan untuk memperkirakan efek dari beberapa tindakan.

Menurut Tersine (1994) simulasi Monte Carlo merupakan simulasi probabilistik, dimana mencari solusi dengan mangambil sampel secara acak. Diperlukan distribusi probabilitas dari variabel yang akan diteliti dan kemudian secara acak mengambil sampel dari distribusi untuk mendapatkan data. Menurut Djati (2007) simulasi Monte Carlo merupakan metode analis is numerik yang me libatkan sampel bilangan acak. Monte Carlo berbentuk simulasi probabilitas yang solusi pemecahan masalahnya menggunakan proses randomisasi 
Langkah-langkah dalam melakukan simulasi Monte Carlo adalah (Heizer dan Render, 2012):

1. Membuat distribusi probabilitas

2. Membangun distribusi probabilitas kumulatif untuk setiap varibel.

3. Membuat interval bilangan acak

4. Menghasilkan bilangan acak

5. Mensimulasikan eskperimen

Proses yang dilakukan untuk dapat melakukan simulasi pengendalian persediaan adalah sebagai berikut (Heizer dan Render, 2012):

1. Mulailah setiap hari yang akan disimulasikan dengan memeriksa apakah ada persediaan yang dipesan baru saja tiba. Jika sudah tiba, maka tambah persediaan saat ini dengan jumlah yang dipesan.

2. Generate permintaan harian dari distribusi probabilitas permintaan untuk bilangan acak yang dipilih.

3. Melakukan perhitungan. Persediaan akhir = persediaan awal dikurangi permintaan.

4. Tentukan apakah persediaan akhir pada hari itu telah mencapai titik pemesanan ulang jika menggunakan pendekatan metode $\mathrm{Q}(\mathrm{B}, \mathrm{Q})$ atau telah mencapai periode pemesanan jika menggunakan pendekatan $\mathrm{P}(\mathrm{t}, \mathrm{E})$

\section{Pembahasan}

Bagan metodologi pengolahan data ditunjukkan pada Gambar 1:

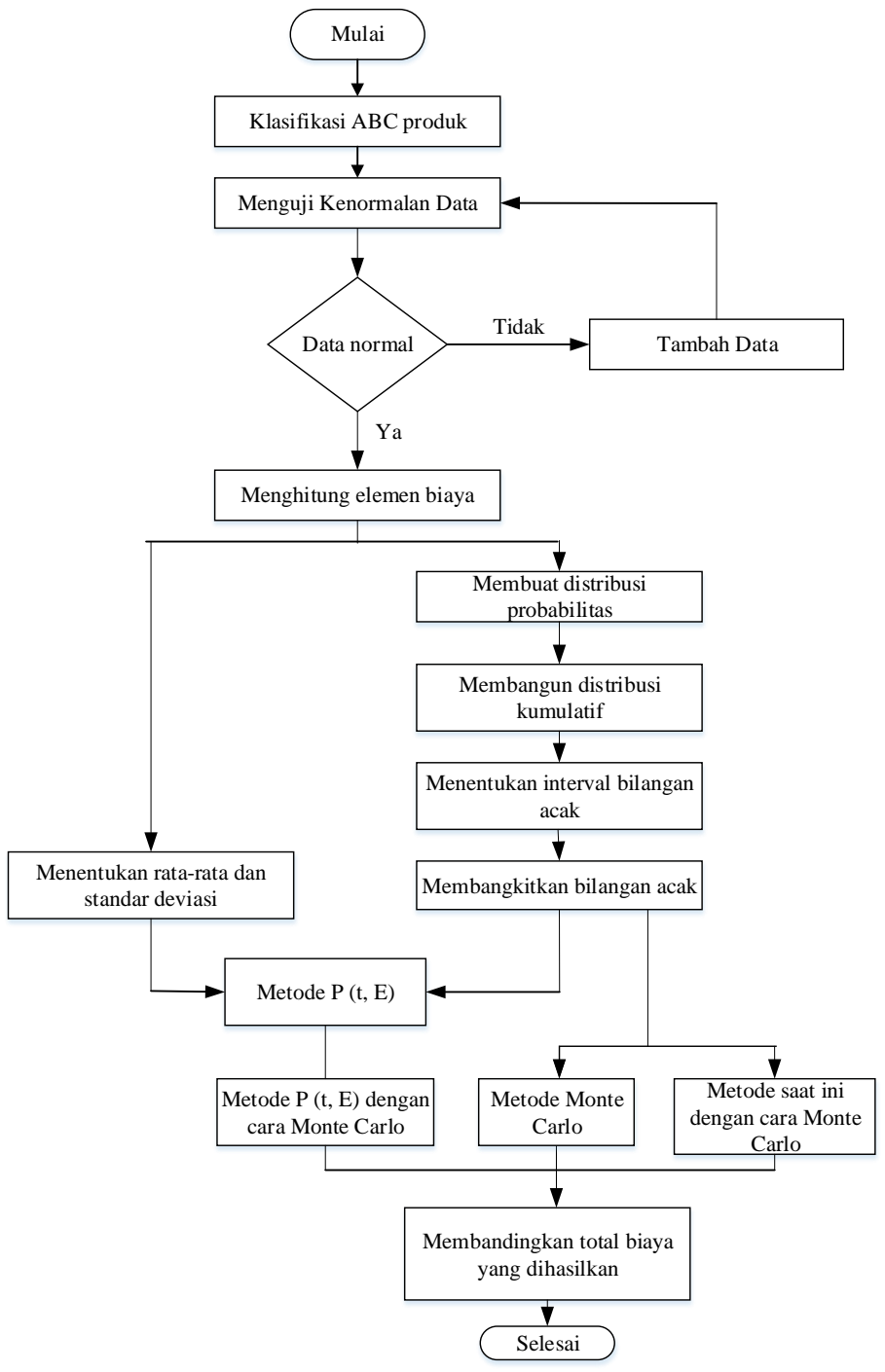

Gambar 1. Bagan Metodologi Pengolahan Data 


\subsection{Klasifikasi ABC}

Klasifikasi ABC pada penelitian ini dilakukan berdasarkan supplier, karena pemesanan barangbarang berasal dari supplier yang sama dan dilakukan secara bersamaan. Oleh karena banyaknya produk yang diamati yaitu 1,232 jenis produk, maka dilakukan klasifikasi ABC. Data yang akan diamati adalah supplier dengan kelas A. Klasifikasi ABC ditunjukkan pada Tabel 1.

Tabel 1. Perhitungan Klasifikasi ABC

\begin{tabular}{|c|c|c|c|c|c|c|}
\hline No & Supplier & & $\begin{array}{l}\text { Penjualan per } \\
\text { Supplier }\end{array}$ & Persentase & $\begin{array}{c}\text { Kumulatif } \\
\text { Persentase }(\%)\end{array}$ & Kelas \\
\hline 1 & PT R & & $5,688,256,300$ & 0.27 & 0.27 & \multirow{5}{*}{ A } \\
\hline 2 & PT S & & $3,888,177,085$ & 0.18 & 0.45 & \\
\hline 3 & PT B & $\mathrm{Rp}$ & $2,568,854,393$ & 0.12 & 0.57 & \\
\hline 4 & PT A & $\mathrm{Rp}$ & $1,635,291,075$ & 0.08 & 0.65 & \\
\hline 5 & PT Q & $\mathrm{Rp}$ & $1,384,869,545$ & 0.07 & 0.71 & \\
\hline 6 & PTE & $\mathrm{Rp}$ & $869,711,638$ & 0.04 & 0.75 & \multirow{9}{*}{ B } \\
\hline 7 & PT F & $\mathrm{Rp}$ & $680,717,731$ & 0.03 & 0.79 & \\
\hline 8 & PT K & $\mathrm{Rp}$ & $505,435,270$ & 0.02 & 0.81 & \\
\hline 9 & PT T & $\mathrm{Rp}$ & $469,080,161$ & 0.02 & 0.83 & \\
\hline 10 & PT O & $\mathrm{Rp}$ & $464,229,885$ & 0.02 & 0.85 & \\
\hline 11 & PT P & $\mathrm{Rp}$ & $448,373,167$ & 0.02 & 0.87 & \\
\hline 12 & PT M & $\mathrm{Rp}$ & $411,419,933$ & 0.02 & 0.89 & \\
\hline 13 & PT J & $\mathrm{Rp}$ & $364,207,892$ & 0.02 & 0.91 & \\
\hline 14 & PT G & $\mathrm{Rp}$ & $354,348,070$ & 0.02 & 0.93 & \\
\hline 15 & PT H & $\mathrm{Rp}$ & $351,559,300$ & 0.02 & 0.94 & \multirow{6}{*}{$\mathrm{C}$} \\
\hline 16 & PTL & $\mathrm{Rp}$ & $292,320,073$ & 0.01 & 0.96 & \\
\hline 17 & PT C & $\mathrm{Rp}$ & $277,742,922$ & 0.01 & 0.97 & \\
\hline 18 & PT I & $\mathrm{Rp}$ & $251,361,838$ & 0.01 & 0.98 & \\
\hline 19 & PT D & $\mathrm{Rp}$ & $203,505,159$ & 0.01 & 0.99 & \\
\hline 20 & PT N & $\mathrm{Rp}$ & $161,252,998$ & 0.01 & 1.00 & \\
\hline
\end{tabular}

\subsection{Menguji Kenormalan Data}

Uji normal dilakukan untuk mengetahui sebaran data penjualan yang te lah didapatkan berdistribusi normal atau tidak. Pengujian dilakukan dengan software IBM SPSS Statistics 21 untuk produkproduk dari supplier kelas A. Uji yang dilakukan adalah Uji Shapiro Wilk, dimana pengujian ini efektif dan valid digunakan untuk sampel yang berukuran kecil. Berdasarkan hasil perhitungan dapat disimpulkan bahwa seluruh data permintaan yang dikumpulkan berdistribusi normal.

\subsection{Perhitungan Biaya}

\subsubsection{Biaya Pesan}

Biaya pesan merupakan biaya yang harus dikeluarkan oleh perusahaan dalam proses pemesanan produk ke supplier. Elemen biaya pesan terdiri dari biaya internet, biaya administrasi, biaya pelabuhan, dan biaya trucking yang berhubungan dengan pemesanan produk. Dengan demikian, total biaya pesan yang dibutuhkan untuk satu kali pesan ditunjukkan dalam Tabel 2.

Tabel 2. Elemen Biaya Pesan

\begin{tabular}{|c|cr|}
\hline Elemen Biaya Pesan & \multicolumn{2}{|c|}{ Besar Biaya } \\
\hline Biaya Internet & $\mathrm{Rp}$ & 432.43 \\
\hline Biaya Administrasi & $\mathrm{Rp}$ & $88,325.83$ \\
\hline Biaya Truck & $\mathrm{Rp}$ & $1,611,433.33$ \\
\hline Biaya Pelabuhan & $\mathrm{Rp}$ & $8,700,000.00$ \\
\hline Total & $\mathrm{Rp}$ & $10,400,191.59$ \\
\hline
\end{tabular}




\subsubsection{B iaya simpan}

Biaya simpan merupakan biaya yang dike luarkan oleh perusahaan akibat melakukan penyimpanan barang di gudang. Elemen biaya simpan terdiri dari biaya modal, biaya gudang, biaya pajak, dan biaya asuransi. Total persentase biaya simpan ditunjukkan pada Tabel 3 .

Tabel 3. Persentase Biaya Simpan

\begin{tabular}{|c|c|}
\hline Biaya & Persentase \\
\hline Modal & $6.25 \%$ \\
\hline Gudang & $7.46 \%$ \\
\hline Pajak & $3.42 \%$ \\
\hline Asuransi & $1.01 \%$ \\
\hline Listrik & $1.21 \%$ \\
\hline Keamanan dan Kebersihan & $4.66 \%$ \\
\hline Total/tahun & $24.01 \%$ \\
\hline
\end{tabular}

\subsubsection{Biaya Stockout}

Biaya stockout merupakan biaya yang dikeluarkan saat perusahaan tidak mampu memenuhi permintaan konsumen karena ketidakadaan stok. Biasanya perusahaan akan merespon kehabisan stok dengan melakukan pemesanan khusus ke supplier agar dapat dilakukan pengiriman barang dengan segera, dimana supplier yang digunakan adalah supplier yang ada di Indonesia dengan harga lebih mahal 15\% dari harga normal.

\subsection{Membangkitkan Bilangan Acak}

Berikut adalah langkah-langkah dalam melakukan simulasi Monte Carlo untuk mendapatkan bilangan acak yang akan digunakan sebagai acuan untuk data demand.

1. Membuat distribusi probabilitas

2. Membangun distribusi probabilitas kumulatif untuk setiap varibel.

3. Membuat interval bilangan acak

4. Menghasilkan bilangan acak

Perhitungan menggunakan metode Monte Carlo dilakukan per produk. Contoh perhitungan bilangan acak untuk Produk UL 1000 ditunjukkan pada Tabel 4.

Tabel 4. Penentuan Bilangan Acak Produk UL 1000

\begin{tabular}{|c|c|c|c|c|c|c|c|c|c|}
\hline Kelas & Batas Bawah & Batas Atas & Titik Tengah & Frekuensi & $\begin{array}{l}\text { Frekuensi } \\
\text { Kumulatif }\end{array}$ & Probalititas & $\begin{array}{c}\text { Probabilitas } \\
\text { Kumulatif }\end{array}$ & \multicolumn{2}{|c|}{ Random } \\
\hline 1 & 3470 & 4107 & 3788.5 & 2 & 2 & 0.17 & 0.17 & 1 & 17 \\
\hline 2 & 4108 & 4745 & 4426.5 & 4 & 6 & 0.33 & 0.50 & 18 & 50 \\
\hline 3 & 4746 & 5383 & 5064.5 & 2 & 8 & 0.17 & 0.67 & 51 & 67 \\
\hline 4 & 5384 & 6021 & 5702.5 & 3 & 11 & 0.25 & 0.92 & 68 & 92 \\
\hline 5 & 6022 & 6659 & 6340.5 & 1 & 12 & 0.08 & 1.00 & 93 & 100 \\
\hline & & & Total & 12 & & 1 & & & \\
\hline
\end{tabular}

Bilangan acak ini akan digunakan untuk perhitungan metode saat ini dan metode usulan. Hal ini dilakukan agar hasil perhitungan metode saat ini dan metode usulan dapat diperbandingkan. Pada metode saat ini dan usulan metode $\mathrm{P}$ ( $\mathrm{t}, \mathrm{E}$ ) menggunakan demand aktual dan cara perhitungan analitik, sedangkan metode usulan metode Monte Carlo menggunakan demand hasil bilangan acak dan cara perhitungan simulasi. Karena perbedaan tersebut maka dilakukan penyesuaian pada metode saat ini dan metode usulan $\mathrm{P}(\mathrm{t}, \mathrm{E})$ dengan mengganti demand aktual menjadi demand hasil bilangan acak pada metode Monte Carlo, dan cara perhitungan menggunakan cara perhitungan Monte Carlo.

\subsection{Metode Saat Ini}

Saat ini Mr. Kitchen melakukan pengendalian berdasarkan perkiraan dari Kepala Gudang, dimana periode pemesanan (t) tiap supplier ditetapkan sama untuk setiap supplier yaitu berturut-turut untuk supplier PT R, PT S, PT B, PT A, PT Q adalah 2 bulan, 2 bulan, 2 bulan, 3 bulan, dan 3 bulan. 
Kuantitas pemesanan ditetapkan dengan mempertimbangkan tingkat persediaan maksimum dan tingkat persediaan produk ketika pemesanan dilakukan. Persediaan maksimum (E) didapatkan dari maksimasi persediaan selama 1 tahun. Dilakukan penyesuaian pada demand, dimana periode pemesanan dan persediaan maksimum yang digunakan perusahaan saat ini, kemudian dimasukkan ke dalam cara perhitungan metode Monte Carlo dengan demand yang digunakan merupakan demand hasil bilangan acak. Contoh perhitungan metode saat ini dengan menggunakan metode Monte Carlo untuk produk UL 1000 ditunjukkan pada Tabel 5, dan total biaya pengendalian persediaan metode saat ini dengan menggunakan metode Monte Carlo untuk produk UL 1000 ditunjukkan pada Tabel 6 .

Tabel 5. Simu lasi Metode Saat Ini dengan Cara Monte Produk UL 1000

\begin{tabular}{|c|c|c|c|c|c|c|c|c|c|c|c|c|}
\hline Bulan & Random & Demand & $\begin{array}{c}\text { Persediaan } \\
\text { Awal }\end{array}$ & $\begin{array}{l}\text { Barang } \\
\text { Datang }\end{array}$ & $\begin{array}{c}\text { Persedia an } \\
\text { Tersedia }\end{array}$ & Demand Terpernhi & Persediaan Akhir & St tock Out & $\begin{array}{c}\text { Persediaan Althir } \\
\text { + Order }\end{array}$ & Pesan? & $\begin{array}{l}\text { Lead } \\
\text { Tme }\end{array}$ & $\begin{array}{c}\text { Kapan Barang } \\
\text { Datang }\end{array}$ \\
\hline Mei & 87 & 5702.5 & 2762 & 0 & 2762 & 2762 & 0 & 2941 & 0 & 0 & 3 & 0 \\
\hline Juni & 93 & 6340.5 & 0 & 0 & 0 & 0 & 0 & 6341 & 0 & 1 & 3 & 5 \\
\hline Juli & 98 & 6340.5 & 0 & 0 & 0 & 0 & 0 & 6341 & 24255 & 0 & 3 & 0 \\
\hline Agustus & 8 & 3788.5 & 0 & 0 & 0 & 0 & 0 & 3789 & 24255 & 1 & 3 & 7 \\
\hline Sepember & 17 & 3788.5 & 0 & 24255 & 24255 & 3789 & 20467 & 0 & 44722 & 0 & 3 & 0 \\
\hline Oktober & 43 & 4426.5 & 20467 & 0 & 20467 & 4427 & 16040 & 0 & 40295 & 1 & 3 & 9 \\
\hline Norember & 86 & 5702.5 & 16040 & 8215 & 24255 & 5703 & 18553 & 0 & 58848 & 0 & 3 & 0 \\
\hline Desember & 81 & 5702.5 & 18553 & 0 & 18553 & 5703 & 12850 & 0 & 53145 & 1 & 3 & 11 \\
\hline Jamuari & 18 & 4426.5 & 12850 & 11405 & 24255 & 4427 & 19829 & 0 & 72974 & 0 & 3 & 0 \\
\hline Febuari & 75 & 5702.5 & 19829 & 0 & 19829 & 5703 & 14126 & 0 & 67271 & 1 & 3 & 13 \\
\hline Maret & 24 & 4426.5 & 14126 & 10129 & 24255 & 4427 & 19829 & 0 & 87100 & 0 & 3 & 0 \\
\hline April & 71 & 5702.5 & 19829 & 0 & 19829 & 5703 & 14126 & 0 & 81397 & 1 & 3 & 15 \\
\hline
\end{tabular}

Tabel 6. Total Biaya Metode Saat Ini dengan Cara Monte Carlo Produk UL 1000

\begin{tabular}{|c|c|c|c|c|c|c|}
\hline Bulan & \multicolumn{2}{|c|}{ Biaya Simpan } & \multicolumn{2}{|c|}{ Biaya Stockout } & Biaya Pesan & Total Biaya \\
\hline Mei & $R p$ & - & $R p$ & $606,478.13$ & $R_{p} \quad-$ & $606,478.13$ \\
\hline Juni & $\mathrm{Rp}$ & - & $R_{p}$ & $1,307,728.13$ & Rp $10,400,191.59$ & Rp $\quad 11,707,919.71$ \\
\hline Juli & $\mathrm{Rp}$ & - & $R p$ & $1,307,728.13$ & $\mathrm{Rp}$ & $\mathrm{Rp} \quad 1,307,728.13$ \\
\hline Agustus & $R p$ & - & $\mathrm{Rp}$ & 781.378 .13 & $R p 10.400 .191 .59$ & $\begin{array}{ll}\mathrm{Rp} & 11.181 .569 .71 \\
\end{array}$ \\
\hline September & $R_{p}$ & $563,063.26$ & $R p$ & - & $\mathrm{Rp}$ & $\mathrm{Rp}_{\mathrm{p}} \quad 563,063.26$ \\
\hline Oktober & $R_{p}$ & $441,283.79$ & $R p$ & - & $\operatorname{Rp} 10,400,191.59$ & $R p \quad 10,841,475.38$ \\
\hline November & Rp & $510,406.33$ & $\mathrm{Rp}$ & - & $\mathrm{Rp}_{\mathrm{p}} \quad-$ & $\mathrm{Rp} \quad 510,406.33$ \\
\hline Desember & $R_{p}$ & $353,522.24$ & $\mathrm{Rp}$ & - & $\operatorname{Rp} 10,400,191.59$ & Rp $\quad 10,753,713.83$ \\
\hline Jamuani & $R_{p}$ & $545,510.95$ & $R p$ & - & $\mathrm{Rp}_{\mathrm{p}}$ & $R_{p} \quad 545,510.95$ \\
\hline Febuari & $\mathrm{Rp}$ & $388,626.86$ & $R p$ & - & $\operatorname{Rp} 10,400,191.59$ & $\mathrm{Rp} \quad 10,788,818.45$ \\
\hline Maret & $R_{p}$ & 545.510 .95 & $\mathrm{Rp}$ & - & $\mathrm{Rp}$ & 545.510 .95 \\
\hline April & $R p$ & $388,626.86$ & $\mathrm{Rp}$ & - & Rp $10,400,191.59$ & $10,788,818.45$ \\
\hline & $R p$ & $3,736,551.25$ & $R p$ & $4,003,312.50$ & Rp $62,401,149.51$ & Rp $\quad 70,141,013.26$ \\
\hline
\end{tabular}

\subsection{Metode $\mathbf{P}(t, E)$}

Metode P (t, E) merupakan metode pengendalian persediaan dengan periode pemesanan yang selalu sama, sedangkan kuantitas pemesanan akan berubah-ubah, sebesar selisih antara tingkat persediaan maksimum dengan jumlah persediaan barang saat pemesanan dilakukan. Dilakukan penyesuaian pada demand sehingga pada perhitungan metode $\mathrm{P}(\mathrm{t}, \mathrm{E})$, demand yang digunakan adalah demand hasil bilangan acak yang digunakan pada Monte Carlo. Hasil perhitungan E dan $\mathrm{t}$ dari metode $\mathrm{P}(\mathrm{t}, \mathrm{E})$ kemudian dimasukkan ke dalam perhitungan cara Monte Carlo. Metode $\mathrm{P}(\mathrm{t}, \mathrm{E})$ pertama-tama menghitung dahulu periode pemesanan optimal, yang ditunjukkan pada Tabel 7.

Tabel 7. Periode Pe mesanan Optimal

\begin{tabular}{|c|c|r|r|r|c|c|}
\hline \multirow{2}{*}{ Supplier } & \multirow{2}{*}{$\mathrm{t}$ (tahun) } & \multirow{2}{*}{$\mathrm{t}$ (bulan) } & \multicolumn{2}{|c|}{ Alternatif(bulan) } & \multicolumn{2}{|c|}{ Altematif(Tahun) } \\
\cline { 4 - 6 } & & & $\mathrm{t}(1)$ & 2.2 & $\mathrm{t}(1)$ \\
\hline PTR & 0.179 & 2.15 & 2.1 & 2.7 & 0.18 \\
\hline PTS & 0.224 & 2.69 & 2.6 & 3.2 & 0.18 \\
\hline PTB & 0.260 & 3.12 & 3.1 & 3.4 & 0.22 \\
\hline PTA & 0.280 & 3.36 & 3.3 & 4.2 & 0.26 \\
\hline PTQ & 0.346 & 4.15 & 4.1 & 0.27 & 0.28 \\
\hline
\end{tabular}


Kemudian berdasarkan Tabel 7 dilakukan perhitungan total biaya, yang akan digunakan sebagai variabel $\mathrm{E}$ dan $\mathrm{t}$ berdasarkan total biaya yang paling kecil. Perbandingan total biaya antara 2 alternatif ditunjukkan pada Tabel 8.

Tabel 8. Perbandingan Total Biaya Alternatif Usulan Metode P (t, E)

\begin{tabular}{|l|rr|rr|}
\hline \multirow{2}{*}{ Supplier } & \multicolumn{4}{|c|}{ Total Biaya } \\
\cline { 2 - 5 } & \multicolumn{3}{|c|}{ Alternatif 1} & \multicolumn{2}{|c|}{ Alternatif 2} \\
\hline PT R & $\mathrm{Rp}$ & $128,354,890.61$ & $\mathrm{Rp}$ & $128,370,062.18$ \\
\hline PT S & $\mathrm{Rp}$ & $106,244,789.09$ & $\mathrm{Rp}$ & $106,147,467.27$ \\
\hline PT B & $\mathrm{Rp}$ & $89,556,619.26$ & $\mathrm{Rp}$ & $89,425,207.88$ \\
\hline PT A & $\mathrm{Rp}$ & $65,467,959.49$ & $\mathrm{Rp}$ & $65,466,379.55$ \\
\hline PT Q & $\mathrm{Rp}$ & $63,081,876.25$ & $\mathrm{Rp}$ & $63,068,349.04$ \\
\hline Total & $\mathrm{Rp}$ & $452,706,134.69$ & $\mathrm{Rp}$ & $452,477,465.93$ \\
\hline
\end{tabular}

Berdasarkan Tabel 8 terlihat bahwa total biaya alternatif 2 lebih kecil, maka hasil perhitungan $\mathrm{E}$ dan $t$ dari alternatif 2 dimasukkan ke cara perhitungan Monte Carlo agar dapat diperbandingkan dengan metode saat ini dan metode Monte Carlo. Contoh perhitungan metode $\mathrm{P}(\mathrm{t}, \mathrm{E})$ dengan menggunakan metode Monte Carlo untuk produk UL 1000 ditunjukkan pada Tabel 9, dan total biaya pengendalian persediaan metode $\mathrm{P}(\mathrm{t}, \mathrm{E})$ dengan menggunakan metode Monte Carlo untuk produk UL 1000 ditunjukkan pada Tabel 10.

Tabel 9. Simu lasi Metode P (t, E) dengan Cara Monte Produk UL 1000

\begin{tabular}{|c|c|c|c|c|c|c|c|c|c|c|c|c}
\hline Bulan & Random & Demand & $\begin{array}{c}\text { Persediaan } \\
\text { Awal }\end{array}$ & $\begin{array}{c}\text { Barang } \\
\text { Datang }\end{array}$ & $\begin{array}{c}\text { Persediaan } \\
\text { Tersedia }\end{array}$ & Demand Terpenuhi & Persediaan Akhir & $\begin{array}{c}\text { Stock Out } \\
\text { Persediaan Akhir } \\
+ \text { Order }\end{array}$ & $\begin{array}{c}\text { Pesan? } \\
\text { Time }\end{array}$ & $\begin{array}{c}\text { Lead } \\
\text { Datang }\end{array}$ \\
\hline Mei & 87 & 5702.5 & 2762 & 0 & 2762 & 2762 & 0 & 2941 & 0 & 0 & 3 & 0 \\
\hline Juri & 93 & 6340.5 & 0 & 0 & 0 & 0 & 0 & 6341 & 0 & 1 & 3 & 5 \\
\hline Juli & 98 & 6340.5 & 0 & 0 & 0 & 0 & 0 & 6341 & 25856 & 0 & 3 & 0 \\
\hline Agustus & 8 & 3788.5 & 0 & 0 & 0 & 0 & 0 & 3789 & 25856 & 1 & 3 & 7 \\
\hline September & 17 & 3788.5 & 0 & 25856 & 25856 & 3789 & 22068 & 0 & 47924 & 0 & 3 & 0 \\
\hline Oktober & 43 & 4426.5 & 22068 & 0 & 22068 & 4427 & 17641 & 0 & 43498 & 1 & 3 & 9 \\
\hline November & 86 & 5702.5 & 17641 & 8215 & 25856 & 5703 & 20154 & 0 & 63652 & 0 & 3 & 0 \\
\hline Desember & 81 & 5702.5 & 20154 & 0 & 20154 & 5703 & 14451 & 0 & 57949 & 1 & 3 & 11 \\
\hline Jamuari & 18 & 4426.5 & 14451 & 11405 & 25856 & 4427 & 21430 & 0 & 79379 & 0 & 3 & 0 \\
\hline Febuari & 75 & 5702.5 & 21430 & 0 & 21430 & 5703 & 15727 & 0 & 73676 & 1 & 3 & 13 \\
\hline Maret & 24 & 4426.5 & 15727 & 10129 & 25856 & 4427 & 21430 & 0 & 95106 & 0 & 3 & 0 \\
\hline April & 71 & 5702.5 & 21430 & 0 & 21430 & 5703 & 15727 & 0 & 89404 & 1 & 3 & 13 \\
\hline
\end{tabular}

Tabel 10. Total Biaya Metode P (t, E) dengan Cara Monte Carlo Produk UL 1000

\begin{tabular}{|c|c|c|c|c|c|c|}
\hline Bulan & \multicolumn{2}{|c|}{ Biaya Simpan } & \multicolumn{2}{|c|}{ Biaya Stockout } & Biaya Pesan & TotalBiaya \\
\hline Mei & $R p$ & - & $R_{p}$ & $606,478.13$ & $\mathrm{Rp} \quad-$ & $\mathrm{Rp} \quad 606,478.13$ \\
\hline Juni & $R p$ & - & $R_{p}$ & $1,307,728.13$ & Rp $10,400,191.59$ & $\operatorname{Rp} \quad 11,707,919.71$ \\
\hline Juli & $\mathrm{Rp}$ & - & $R p$ & 1.307 .728 .13 & $\mathrm{Rp} \quad \cdots$ & $\begin{array}{ll}R p & 1.307 .728 .13\end{array}$ \\
\hline Agustus & $\mathrm{Rp}$ & - & $R_{p}$ & $781,378.13$ & Rp $10,400,191.59$ & Rp $11,181,569.71$ \\
\hline September & $R p$ & $607,118.40$ & $\mathrm{Rp}_{\mathrm{p}}$ & - & $\mathrm{Rp} \quad-$ & Rp $\quad 607,118.40$ \\
\hline Oktober & Rp & $485,338.93$ & $\mathrm{Rp}$ & - & Rp $10,400,191.59$ & Rp $\quad 10,885,530.51$ \\
\hline November & $\mathrm{Rp}$ & $554,461.47$ & $\mathrm{Rp}$ & - & $\mathrm{Rp}_{\mathrm{p}} \quad-$ & $\mathrm{Rp}_{\mathrm{p}} \quad 554,461.47$ \\
\hline Desember & Rp & $397,577.37$ & $\mathrm{Rp}$ & - & Rp $10,400,191.59$ & $\begin{array}{ll}\text { Rp } \quad 10,797,768.96 \\
\end{array}$ \\
\hline Jamuari & $R_{p}$ & $589,566.09$ & $\mathrm{Rp}$ & - & $\mathrm{R}_{p} \quad-$ & $\begin{array}{ll}\text { Rp } & 589,566.09 \\
\end{array}$ \\
\hline Febuari & $R p$ & 432.682 .00 & $\mathrm{Rp}$ & - & Rp 10.400 .191 .59 & $\mathrm{Rp} \quad 10.832 .873 .58$ \\
\hline Maret & $R p$ & $589,566.09$ & $R p$ & - & $\mathrm{Rp} \quad-$ & $\begin{array}{ll}\mathrm{Rp} & 589,566.09 \\
\end{array}$ \\
\hline April & $\mathrm{Rp}$ & $432,682.00$ & $R p$ & - & Rp $10,400,191.59$ & Rp $\quad 10,832,873.58$ \\
\hline & $R_{p}$ & $4,088,992.33$ & $R p$ & $4,003,312.50$ & $\operatorname{Rp} 62,401,149.51$ & Rp $\quad 70,493,454.34$ \\
\hline
\end{tabular}

\subsection{Metode Monte Carlo}

Pada metode Monte Carlo, nilai E dan t didapat dari hasil simulasi menggunakan solver dengan metode Evolutionary yang terdapat pada software Microsoft Excel. Nilai E dan t dicari yang teroptimal dengan tujuan mendapat total biaya yang paling murah. Nilai $\mathrm{E}$ yang didapat adalah 32870.78 unit atau 32871 unit dan nilait adalah 7 bulan.

Formulasi pemecahan permasalahan dengan menggunakan solver metode Evolutionary adalah sebagai berikut:

1. Fungsi tujuan = total biaya (biaya simpan + biaya pesan + biaya stockout) selama 1 tahun 
2. Minimasi total biaya (biaya simpan + biaya pesan + biaya stockout) selama 1 tahun

3. Variabel keputusan $=$ nilai $\mathrm{E}$ dan $\mathrm{t}$

4. Kendala $=$

Nilai $\mathrm{t}=$ integer

Nilai $\mathrm{t} \leq 12$

Nilai $t \geq 1$

Nilai E untuk produk UL $1000 \leq 60000$

Nilai E untuk produk UL $1000 \geq 0$

Dan seterusnya untuk seluruh produk pada supplier yang sama, dengan batas atas nilai $\mathrm{E}$ sebesar 10 kali dari maksimasi data persediaan selama 1 tahun

5. Pemecahan metode Monte Carlo menggunakan bantuan Solver pada Microsoft Excel dengan teknik pemecahan masalah adalah Evolutionary.

Contoh perhitungan metode Monte Carlo untuk produk UL 1000 ditunjukkan pada Tabel 11, dan total biaya pengendalian persediaan metode Monte Carlo untuk produk UL 1000 ditunjukkan pada Tabel 12.

Tabel 11. Simu lasi Metode Monte Produk UL 1000

\begin{tabular}{|c|c|c|c|c|c|c|c|c|c|c|c|c|}
\hline Bulan & Random & Demand & $\begin{array}{c}\text { Persediaan } \\
\text { Awal }\end{array}$ & $\begin{array}{l}\text { Barang } \\
\text { Datang }\end{array}$ & $\begin{array}{c}\text { Persedia an } \\
\text { Tersedia }\end{array}$ & Demand Terpenuhi & Perse diaan Akhir & Stock Out & $\begin{array}{c}\text { Persediaan Akhir } \\
\text { + Order }\end{array}$ & Pesan? & $\begin{array}{l}\text { Lead } \\
\text { Time }\end{array}$ & $\begin{array}{c}\text { Kapan Barang } \\
\text { Datang }\end{array}$ \\
\hline Mei & 87 & 5702.5 & 2762 & 0 & 2762 & 2762 & 0 & 2941 & 0 & 0 & 3 & 0 \\
\hline Juni & 93 & 6340.5 & 0 & 0 & 0 & 0 & 0 & 6341 & 0 & 0 & 3 & 0 \\
\hline Juli & 98 & 6340.5 & 0 & 0 & 0 & 0 & 0 & 6341 & 0 & 0 & 3 & 0 \\
\hline Agustus & 8 & 3788.5 & 0 & 0 & 0 & 0 & 0 & 3789 & 0 & 0 & 3 & 0 \\
\hline September & 17 & 3788.5 & 0 & 0 & 0 & 0 & 0 & 3789 & 0 & 0 & 3 & 0 \\
\hline Oktober & 43 & 4426.5 & 0 & 0 & 0 & 0 & 0 & 4427 & 0 & 0 & 3 & 0 \\
\hline November & 86 & 5702.5 & 0 & 0 & 0 & 0 & 0 & 5703 & 0 & 1 & 3 & 10 \\
\hline Desember & 81 & 5702.5 & 0 & 0 & 0 & 0 & 0 & 5703 & 32871 & 0 & 3 & 0 \\
\hline Januari & 18 & 4426.5 & 0 & 0 & 0 & 0 & 0 & 4427 & 32871 & 0 & 3 & 0 \\
\hline Febuari & 75 & 5702.5 & 0 & 32871 & 32871 & 5703 & 27168 & 0 & 27168 & 0 & 3 & 0 \\
\hline Maret & 24 & 4426.5 & 27168 & 0 & 27168 & 4427 & 22742 & 0 & 22742 & 0 & 3 & 0 \\
\hline April & 71 & 5702.5 & 22742 & 0 & 22742 & 5703 & 17039 & 0 & 17039 & 0 & 3 & 0 \\
\hline
\end{tabular}

Tabel 12. Total Biaya Metode Monte Carlo Produk UL 1000

\begin{tabular}{|c|c|c|c|c|c|c|c|}
\hline Bulan & \multicolumn{2}{|c|}{ Biaya Simpan } & \multicolumn{2}{|c|}{ Biaya Stockout } & Biaya Pesan & \multicolumn{2}{|r|}{ TotalBiaya } \\
\hline Mei & $R p$ & - & $\mathrm{Rp}$ & $606,478.13$ & $R p$ & $R p$ & $606,478.13$ \\
\hline Juni & $\mathrm{Rp}$ & - & $R p$ & $1,307,728.13$ & $\mathrm{Rp}$ & $\mathrm{Rp}$ & $1,307,728.13$ \\
\hline Juli & $\mathrm{Rp}$ & - & $R p$ & $1,307,728.13$ & $\mathrm{Rp}$ & $R p$ & $1,307,728.13$ \\
\hline Agustus & $\mathrm{Rp}$ & - & $\mathrm{Rp}$ & $781,378.13$ & $\mathrm{Rp}$ & $R p$ & $781,378.13$ \\
\hline September & $\mathrm{Rp}$ & - & $R p$ & $781,378.13$ & $\mathrm{Rp}$ & $R_{p}$ & $781,378.13$ \\
\hline Oktober & $R p$ & - & $\mathrm{Rp}$ & $912,965.63$ & $\mathrm{Rp} \quad-$ & $R p$ & $912,965.63$ \\
\hline November & $\mathrm{Rp}$ & - & $R p$ & $1,176,140.63$ & Rp $10,400,191.59$ & $R p$ & $11,576,332.21$ \\
\hline Desember & $\mathrm{Rp}$ & - & Rp & $1,176,140.63$ & $\mathrm{Rp} \quad-$ & $R p$ & $1,176,140.63$ \\
\hline Januari & $\mathrm{Rp}$ & - & $R p$ & $912,965.63$ & $\mathrm{Rp}$ & $R p$ & $912,965.63$ \\
\hline Febuari & $R p$ & $747,438.91$ & $\mathrm{Rp}$ & - & $\mathrm{Rp}$ & $R_{p}$ & $747,438.91$ \\
\hline Maret & $R p$ & $625,659.44$ & $\mathrm{Rp}$ & - & $\mathrm{Rp}$ & $R_{p}$ & $625,659.44$ \\
\hline April & $R p$ & $468,775.35$ & $R p$ & - & $\mathrm{Rp}$ & $R_{p}$ & $468,775.35$ \\
\hline & $R p$ & $1,841,873.70$ & $\mathrm{Rp}$ & $8,962,903.13$ & Rp $10,400,191.59$ & Rp & $21,204,968.41$ \\
\hline
\end{tabular}

\subsection{Perbandingan Biaya Pengendalian Persediaan Me tode Saat Ini dan Us ulan}

Setelah menghitung total biaya untuk setiap produk pada setiap supplier, langkah selanjutnya adalah membandingkan total biaya untuk metode saat ini dan metode usulan, untuk mengetahui metode mana yang terbaik. Rangkuman total biaya untuk masing-masing metode ditunjukkan pada Tabel 13 dan Tabel 14. Sedangkan rangkuman setiap elemen biaya pada metode usulan ditunjukkan pada Tabel 15 sampai dengan Tabel 17. 
Tabel 13. Rangku man Total Biaya Metode Saat Ini dengan Cara Monte Carlo

\begin{tabular}{|c|c|c|c|c|c|c|c|c|}
\hline \multirow{2}{*}{ Supplier } & \multicolumn{8}{|c|}{ Monte Carlo Saat Ini } \\
\hline & \multicolumn{2}{|r|}{ Biaya Simpan } & \multicolumn{2}{|c|}{ Biaya Stockout } & \multicolumn{2}{|r|}{ Biaya Pesan } & \multicolumn{2}{|r|}{ Total Biaya } \\
\hline PT R & $\mathrm{Rp}$ & $132,986,091.27$ & $\mathrm{Rp}$ & $123,810,322.50$ & $\mathrm{Rp}$ & $62,401,149.51$ & $\mathrm{Rp}$ & $319,197,563.28$ \\
\hline PT S & $\mathrm{Rp}$ & $768,964,087.58$ & $\mathrm{Rp}$ & $85,922,157.86$ & $\mathrm{Rp}$ & $62,401,149.51$ & $\mathrm{Rp}$ & $917,287,394.96$ \\
\hline PT B & $\mathrm{Rp}$ & $1,564,295,532.39$ & $\mathrm{Rp}$ & $41,657,821.99$ & $\mathrm{Rp}$ & $62,401,149.51$ & $\mathrm{Rp}$ & $1,668,354,503.89$ \\
\hline PT A & $\mathrm{Rp}$ & $471,279,232.94$ & $\mathrm{Rp}$ & $43,261,336.54$ & $\mathrm{Rp}$ & $41,600,766.34$ & $\mathrm{Rp}$ & $556,141,335.82$ \\
\hline PT Q & $\mathrm{Rp}$ & $664,176,892.41$ & $\mathrm{Rp}$ & $41,055,847.69$ & $\mathrm{Rp}$ & $41,600,766.34$ & $\mathrm{Rp}$ & $746,833,506.44$ \\
\hline Total & $\mathrm{Rp}$ & $3,601,701,836.59$ & $\mathrm{Rp}$ & $335,707,486.58$ & $\mathrm{Rp}$ & $270,404,981.23$ & $\mathrm{Rp}$ & $4,207,814,304.40$ \\
\hline
\end{tabular}

Tabel 14. Rangkuman Total Biaya Metode P (t, E) dengan Cara Monte Carlo dan Metode Monte Carlo

\begin{tabular}{|c|rr|rr|}
\hline Supplier & \multicolumn{2}{|c|}{ Monte Carlo } & \multicolumn{2}{c|}{$\begin{array}{c}\text { Metode P dengan Cara } \\
\text { Monte Carlo }\end{array}$} \\
\hline PT R & $\mathrm{Rp}$ & $344,025,523.71$ & $\mathrm{Rp}$ & $332,876,057.24$ \\
\hline PT S & $\mathrm{Rp}$ & $418,759,798.76$ & $\mathrm{Rp}$ & $2,219,617,330.45$ \\
\hline PT B & $\mathrm{Rp}$ & $199,789,288.48$ & $\mathrm{Rp}$ & $894,801,989.69$ \\
\hline PT A & $\mathrm{Rp}$ & $182,667,555.78$ & $\mathrm{Rp}$ & $577,800,024.24$ \\
\hline PT Q & $\mathrm{Rp}$ & $211,440,413.97$ & $\mathrm{Rp}$ & $524,921,592.55$ \\
\hline Total & $\mathrm{Rp}$ & $1,356,682,580.71$ & $\mathrm{Rp}$ & $4,550,016,994.17$ \\
\hline
\end{tabular}

Tabel 15. Rangku man Biaya Pesan Metode P (t, E) dengan Cara Monte Carlo dan Metode Monte Carlo

\begin{tabular}{|c|lr|lr|}
\hline Supplier & \multicolumn{2}{|c|}{ Monte Carlo } & \multicolumn{2}{c|}{$\begin{array}{c}\text { Metode P dengan Cara } \\
\text { Monte Carlo }\end{array}$} \\
\hline PT R & $\mathrm{Rp}$ & $10,400,191.59$ & $\mathrm{Rp}$ & $62,401,149.51$ \\
\hline PT S & $\mathrm{Rp}$ & $10,400,191.59$ & $\mathrm{Rp}$ & $62,401,149.51$ \\
\hline PT B & $\mathrm{Rp}$ & $10,400,191.59$ & $\mathrm{Rp}$ & $41,600,766.34$ \\
\hline PT A & $\mathrm{Rp}$ & $10,400,191.59$ & $\mathrm{Rp}$ & $31,200,574.76$ \\
\hline PT Q & $\mathrm{Rp}$ & $10,400,191.59$ & $\mathrm{Rp}$ & $31,200,574.76$ \\
\hline Total & $\mathrm{Rp}$ & $52,000,957.93$ & $\mathrm{Rp}$ & $228,804,214.89$ \\
\hline
\end{tabular}

Tabel 16. Rangku man Biaya Simpan Metode P (t, E) dengan Cara Monte Carlo dan Metode Monte Carlo

\begin{tabular}{|c|rr|rr|}
\hline Supplier & \multicolumn{2}{|c|}{ Monte Carlo } & \multicolumn{2}{c|}{$\begin{array}{c}\text { Metode P dengan Cara } \\
\text { Monte Carlo }\end{array}$} \\
\hline PTR & $\mathrm{Rp}$ & $31,078,279.46$ & $\mathrm{Rp}$ & $146,047,905.23$ \\
\hline PT S & $\mathrm{Rp}$ & $175,592,141.12$ & $\mathrm{Rp}$ & $1,905,338,257.08$ \\
\hline PT B & $\mathrm{Rp}$ & $17,623,589.97$ & $\mathrm{Rp}$ & $778,767,056.69$ \\
\hline PT A & $\mathrm{Rp}$ & $65,573,049.33$ & $\mathrm{Rp}$ & $493,277,104.85$ \\
\hline PT Q & $\mathrm{Rp}$ & $101,291,178.82$ & $\mathrm{Rp}$ & $447,693,066.67$ \\
\hline Total & $\mathrm{Rp}$ & $391,158,238.71$ & $\mathrm{Rp}$ & $3,771,123,390.52$ \\
\hline
\end{tabular}

Tabel 17. Rangkuman Biaya Stockout Metode P (t, E) dengan Cara Monte Carlo dan Metode Monte Carlo

\begin{tabular}{|c|rr|lr|}
\hline Supplier & \multicolumn{2}{|c|}{ Monte Carlo } & \multicolumn{2}{c|}{$\begin{array}{c}\text { Metode P dengan Cara } \\
\text { Monte Carlo }\end{array}$} \\
\hline PT R & $\mathrm{Rp}$ & $302,547,052.66$ & $\mathrm{Rp}$ & $124,427,002.50$ \\
\hline PT S & $\mathrm{Rp}$ & $232,767,466.06$ & $\mathrm{Rp}$ & $251,877,923.86$ \\
\hline PT B & $\mathrm{Rp}$ & $171,765,506.93$ & $\mathrm{Rp}$ & $74,434,166.66$ \\
\hline PT A & $\mathrm{Rp}$ & $106,694,314.86$ & $\mathrm{Rp}$ & $53,322,344.63$ \\
\hline PT Q & $\mathrm{Rp}$ & $99,749,043.56$ & $\mathrm{Rp}$ & $46,027,951.12$ \\
\hline Total & $\mathrm{Rp}$ & $913,523,384.07$ & $\mathrm{Rp}$ & $550,089,388.77$ \\
\hline
\end{tabular}


Metode usulan terpilih adalah metode yang mempunyai total biaya pengendalian persediaan terkecil. Dari Tabel 14 terlihat bahwa metode Monte Carlo mempunyai total biaya yang paling kecil. Selanjutnya dilakukan perhitungan untuk mengetahui penghematan jika menggunakan metode saat ini dan metode usulan. Perhitungan penghematan biaya ditunjukkan pada Tabel 18.

Tabel 18. Perhitungan Penghematan Biaya

\begin{tabular}{|c|rr|rr|rr|c|}
\hline \multirow{2}{*}{ Biaya } & \multicolumn{2}{|c|}{ Metode Saat Ini } & \multicolumn{2}{|c|}{ Metode Usulan } & \multicolumn{3}{c|}{ Selisih } \\
\cline { 6 - 8 } & & & & & \multicolumn{2}{c|}{$\mathrm{Rp}$} & $\%$ \\
\hline Biaya Pesan & $\mathrm{Rp}$ & $270,404,981.23$ & $\mathrm{Rp}$ & $52,000,957.93$ & $\mathrm{Rp}$ & $218,404,023.30$ & 80.77 \\
\hline Biaya Simpan & $\mathrm{Rp}$ & $3,601,701,836.59$ & $\mathrm{Rp}$ & $391,158,238.71$ & $\mathrm{Rp}$ & $3,210,543,597.88$ & 89.14 \\
\hline Biaya Stockout & $\mathrm{Rp}$ & $335,707,486.58$ & $\mathrm{Rp}$ & $913,523,384.07$ & $-\mathrm{Rp}$ & $577,815,897.49$ & -172.12 \\
\hline Total Biaya & $\mathrm{Rp}$ & $4,207,814,304.40$ & $\mathrm{Rp}$ & $1,356,682,580.71$ & $\mathrm{Rp}$ & $2,851,131,723.69$ & 67.76 \\
\hline
\end{tabular}

\subsection{Analis is}

Dari Tabel 13 terlihat bahwa biaya simpan merupakan elemen biaya yang relatif besar dibandingkan dengan biaya pesan dan biaya stockout, yaitu sebesar $85 \%$ dari total biaya pengendalian persediaan. Hal ini dikarenakan periode pemesanan yang ditetapkan perusahaan tidak terlalu besar sedangkan persediaan maksimum yang ditetapkan cukup besar, sehingga kuantitas pemesanan yang dilakukan perusahaan cukup besar pula.

Metode pengendalian persediaan yang diusulkan secara garis besar ada dua alternatif, yaitu: metode $\mathrm{P}$ ( $\mathrm{t}, \mathrm{E})$ dan Monte Carlo. Namun, kedua metode tersebut tidak dapat dibandingkan secara langsung. Hal ini disebabkan adanya perbedaan besar demand dan cara perhitungan total biaya pengendalian persediaan. Demand pada metode P (t, E) adalah demand aktual, sedangkan pada metode Monte Carlo didapatkan dari hasil membangkitkan bilangan acak. Selain itu, metode P (t, E) menggunakan pendekatan analitik, sedangkan Monte Carlo menggunakan simulasi. Dari Tabel 14 terlihat bahwa total biaya dengan metode Monte Carlo relatif lebih kecil dibandingkan Metode $\mathrm{P}$ (t, E) dengan cara Monte Carlo dengan selisih sebesar Rp. 3,193,334,413.47.

Dari Tabel 15 terlihat bahwa biaya pesan yang dihasilkan metode Monte Carlo relatif lebih kecil dibandingkan metode P (t, E) dengan cara Monte Carlo. Hal ini disebabkan periode pemesanan pada Monte Carlo relatif lebih lama, yaitu bervariasi dari 7 sampai 9 bulan, sedangkan pada metode $\mathrm{P}(\mathrm{t}, \mathrm{E})$ dengan cara Monte Carlo bervariasi dari 2 sampai 4 bulan. Oleh karena periode pemesanan yang dihasilkan lebih lama maka pemesanan akan lebih jarang, sehingga biaya pesan yang dihasilkan metode Monte Carlo lebih murah

Dari Tabel 16 terlihat bahwa biaya simpan yang dihasilkan metode Monte Carlo relatif lebih kecil dibandingkan metode P (t, E) dengan cara Monte Carlo. Hal ini disebabkan tingkat persediaan maksimum yang dihasilkan oleh metode $\mathrm{P}$ ( $\mathrm{t}, \mathrm{E})$ dengan cara Monte Carlo relatif lebih besar dibandingkan Monte Carlo. Disamping itu periode pemesanan relatif lebih cepat dibandingkan Monte Carlo, sehingga pada metode P (t, E) dengan cara Monte Carlo dituntut untuk membeli barang dalam jumlah yang lebih banyak sedangkan waktu pemesanan cepat, sehingga pada metode $\mathrm{P}$ ( $\mathrm{t}, \mathrm{E})$ dengan cara Monte Carlo akan terus menerus mengisi gudang hingga batas maksimum gudang.

Dari Tabel 17 terlihat bahwa biaya stockout yang dihasilkan metode P (t, E) dengan cara Monte Carlo relatif lebih kecil dibandingkan metode Monte Carlo. Hal ini disebabkan karena metode Monte Carlo baik untuk Monte Carlo dan Metode P (t, E) dengan cara Monte Carlo melakukan pengendalian persediaan pada awal yang baru. Hal ini menyebabkan ketika awal perencanaan, tidak diperhitungkan barang yang akan datang dari perencanaan sebelumnya. Oleh karena itu, saat periode pemesanan yang dihasilkan pada metode Monte Carlo relatif cukup besar, maka pada awal perencanaan sampai barang datang tidak terdapat pemenuhan permintaan dan menyebabkan terjadinya stockout.

Dari Tabel 18 terlihat bahwa total biaya pengendalian persediaan pada metode usulan, yaitu metode Monte Carlo re latif lebih kecil dibandingkan dengan metode saat ini, dengan penghematan sebesar 
Rp 2,851,131,723.69 atau 67.76\%. Penghematan tersebut dihasilkan dari penurunan biaya simpan dan biaya pesan yang cukup signifikan, yaitu masing-masing sebesar $89.14 \%$ dan $80.77 \%$, walaupun terjadi peningkatan biaya stockout sebesar $172.12 \%$. Oleh karena itu, metode usulan dapat diterapkan oleh perusahaan.

\section{Kesimpulan dan Saran}

\subsection{Kesimpulan}

Berdasarkan hasil pengolahan data dan analisis, maka didapatkan beberapa kesimpulan adalah sebagai berikut:

1. Kelemahan metode pengendalian persediaan perusahaan saat ini adalah besarnya periode pemesanan dan tingkat persediaan maksimum yang ditetapkan perusahaan. Hal ini menyebabkan tingginya biaya simpan yang timbul, yaitu sebesar Rp. 3,601,701,836.59 atau $85 \%$ dari total biaya pengendalian persediaan.

2. Metode pengendalian persediaan yang sebaiknya diterapkan perusahaan adalah metode Monte Carlo dimana periode pemesanan yang ditetapkan untuk PT R, PT S, PT B, PT A, dan PT Q berturut-turut sebesar 7 bulan, 9 bulan, 9 bulan, 9 bulan, dan 9 bulan.

3. Manfaat yang dapat diperoleh perusahaan dari penerapan metode pengendalian persediaan usulan adalah terjadinya penghematan sebesar Rp. 2,851,131,723.69 atau sebesar $67.76 \%$ dari total biaya pengendalian persediaan keseluruhan.

\subsection{Saran}

Berikut beberapa saran yang perlu diperhatikan perusahaan dalam menerapkan metode pengendalian persediaan usulan:

1. Perusahaan perlu me lakukan sosialisasi mengenai perubahan metode pengendalian perusahaan kepada pihak yang berkepentingan yaitu Kepada Gudang.

2. Perusahaan perlu melakukan pengaturan area gudang untuk penempatan barang yang disimpan.

3. Selanjutnya disarankan melakukan penelitan dengan cara Monte Carlo dengan menambah jumlah data yang akan diteliti, misalnya data per hari atau per minggu.

\section{Daftar Pustaka}

Djati, Bonett Satya Lelono, (2007), Simulasi Teori dan Aplikasinya, Penerbit ANDI, Yogyakarta.

Heizer, Jay \& Render, Barry, (2012), Operation Managements (Flexibel Edition), Prentice Hall Inc, New Jersey.

Hidayat, Anwar, (2013), "Pengertian dan Rumus Uji Saphiro Wilk", https $/ /$ www.statistikian.com/2013/01/saphiro-wilk.html, Diakses pada hari Kamis, 23 Mei 2019 Pk. 15.00 WIB.

Hidayat, Anwar. (2013), "Tutuorial Uji Normalitas dengan SPSS Lengkap", https $/ /$ www.statistikian.com/2013/02/uji-normalitas-pada-spss.html, Diakses pada hari Kamis, 23 Mei 2019 Pk. 15.00 WIB.

Rangkuti, Freddy, (2007), Manajemen Persediaan: Aplikasi di Bidang Bisnis, Raja Grafindo Persada, Jakarta.

Smith, Spencer, (1989), Computer Based Production and Inventory Control, Prentice Hall, Inc, New Jersey.

Tersine, Richard, (1994), Principles of Inventory and Materials Management, Prentice Hall, Inc, New Jersey. 
US ULAN PENGENDALIAN PERS EDIAAN (Mel vita S., dkk.)

Widyadana, I Gede Agus., Tanudireja, Alan Darmasaputra., Teng, Hui-Ming. (2017), "Optimal Inventory Policy for Stochastic Demand Using Monte Carlo Simulation and Evolutionary Algorithm". Jirae, Vol 2 (1), pp. 8-11

Yamit, Zulian., (1999), Manajemen Persediaan, Ekonisia Fakultas Ekonomi UII, Yogyakarta. 